\title{
Arbuscular mycorrhizae and growth enhancement of micropropagated Prunus rootstock in different soilless potting mixes
}

\author{
Victoria Estaun, Cinta Calvet and Amelia Camprubi
}

\begin{abstract}
Estaun, V., Calvet, C. \& CAmprubi, A. 1994. Arbuscular mycorrhizae and growth enhancement of micropropagated Prunus rootstock in different soilless potting mixes. Agricultural Science in Finland 3: 263-267. (Departament de Patologia Vegetal, IRTA, Centre de Cabrils, 08348 Cabrils, Barcelona, Spain.)
\end{abstract}

The receptivity of two peat based potting mixes to AM colonisation was studied with the almond $\mathrm{x}$ peach clone GF677 as host plant. Four fungi were assayed: Glomus mosseae, Glomus intraradices, Glomus sp (E3) and Acaulospora laevis. The response of the four fungi varied with the potting mix used, stressing the importance of the growing media on the functionality of the mycorrhizal symbiosis.

Key words: growth substrate, receptivity, micropropagation, fungal specificity

\section{Introduction}

Propagation of fruit rootstocks by in vitro techniques is done widely and has become a standard procedure in many nurseries. In these circunstances, the plantlets are transferred from sterile in vitro media to potting mixes prepared with organic substrates and inorganic conditioners which lack arbuscular mycorrhizal fungi (AMF) propagules. Fruit tree crops, the prunus species in particular (GILMORE 1971), develop arbuscular mycorrhizae (AM). The early inoculation of plantlets with $\mathrm{AM}$ fungi in the nursery could enhance plant growth and increase field trasplant survival (GIANINAZZI et al. 1989). The receptivity of the organic substrates used in the potting mixes to the AMF and the effects of the inoculation on plant growth have been little studied. CALVET et al. (1992) found that certain types of peat and composted substrates had a negative effect on the establishment of the AM symbiosis, although the AMF germination and early mycelial growth were not affected, and suggest a biological cause for the inhibition. VI-
DAL et al. (1992) found that the symbiosis could be established in peat:sand mixes although soil:sand mixes were more conducive to AM root colonisation of micropropagated avocado plants. SCHUBERT et al. (1990) working on micropropagated grapevine found that the AMF colonised the roots in all peat based media used, but only when soil was added to the mixes there was a significant response of the plant to the inoculation. Vestberg (1992) found that sand fertilised with bone meal was superior to rich based peat substrates in initiating rapid AM colonisation and sporulation of the AMF used. BIERMANN and LINDERMAN (1983) have shown also that the addition of soil to peat induces growth responses to AMF inoculation. Nonetheless commercial growers are reluctant to add soil to their potting mixes due to the increase in weight and the risk of introducing soil borne pathogens.

This work has studied the receptivity of two different peat based mixes, without added soil, to four AM fungi and the effects of the inoculation on plant growth. 


\section{Material and methods}

The transfer from the weaning media to the substrate used in the growth and hardening phase of the plantlets was targeted as the easiest step to perform the arbuscular-mycorrhizal inoculation in the nursery.

\section{Plant material and conditions of growth}

The plant used was a Prunus persica $x$ Prunus amygdalus clone: GF677 widely used as both peach and almond rootstock. Rooted plantlets were obtained from Agromillora Catalana S.A. and were inoculated and grown in pots of $12 \mathrm{~cm}$ diameter. There were 5 treatments per potting mix: Control, inoculated with $G$. mosseae, inoculated with G. intraradices, inoculated with Glomus sp. (E3) and inoculated with A. laevis. Pots were randomised and grown under greenhouse conditions. After 14 weeks the plants were harvested. Plant height, weight and stem diameter were measured. Root colonisation was assessed after staining (PHILlips and HaYMAn 1970) using the grid-line intersect method (GIOVANETTI and MosSe 1980). Results from both mixes were analysed separately using ANOVA and Tuckey's test for multiple range comparisons.

\section{Arbuscular mycorrhizal fungi inoculation}

The fungi employed were: Glomus mosseae (Nicol. \& Gerd.) Gerdemann \& Trappe, Glomus intraradices Schenck \& Smith, Glomus sp (E3) and Acaulospora laevis Gerdemann \& Trappe. To ensure sufficient AM propagules, $20 \mathrm{~g}$ of soil containing spores, mycelia and mycorrhizal roots from heavily colonised pot cultures were used as inoculum and placed under the plantlet roots at the moment of the transfer from the weaning media.

\section{Potting mixes}

Two sphagnum peat types were selected : Floratorf and TKS-1 both are widely used in nurseries and have similar physical properties (Table 1).
Table 1. Physicochemical properties of the two types of peat used for the potting mixes (after AlDRUFEU et al. 1983).

\begin{tabular}{lcr}
\hline & Floratorf & TKS-1 \\
\hline pH $\mathrm{H}_{2} \mathrm{O}$ & 3.9 & 6.87 \\
$\mathrm{E} . \mathrm{C} .25^{\circ} \mathrm{C}(\mathrm{mmhos} / \mathrm{cm})$ & 155 & 946 \\
Bulk density $\left(\mathrm{g} / \mathrm{cm}^{3}\right)$ & 0.095 & 0.076 \\
Total pore space $(\% \mathrm{v})$ & 93.44 & 94.75 \\
Air $(\%$ v) & 19.02 & 26.69 \\
Easily available & 35.2 & 37.9 \\
water $(\% \mathrm{v})$ & & \\
Absorption capacity & 1042 & 1009 \\
$(\mathrm{~g} \mathrm{H} \mathrm{O} / 100 \mathrm{~g} \mathrm{d.m})$. & & 140 \\
added $\mathrm{N}(\mathrm{mg} / \mathrm{l})$ & - & 120 \\
added $\mathrm{P}(\mathrm{mg} / \mathrm{l})$ & - & 220 \\
added $\mathrm{K}(\mathrm{mg} / \mathrm{l})$ & - &
\end{tabular}

TKS- 1 comes as a ready to use peat, neutralised and amended while Floratorf has a pH of 3.9 and had to be neutralised with calcium carbonate to reach a $\mathrm{pH}$ of 6.5 before using it. Both organic substrates were mixed (50:50, v:v) with perlite and used without prior sterilisation.

\section{Results and discussion}

The four AMF studied colonised the plant roots in both substrate mixes, although there were differences in the percentage colonisation achieved (Table 2 and 3). These differences can be attributed to either a certain host preference (ESTAUN et al. 1987) or to the characteristics of the substrate (Table 1) that might be more suitable depending on the fungus studied (GUTTAY 1982, Nemec 1987, Calvet 1989). In the TKS-1 mix $G$. intraradices achieved the highest level of root colonisation. In the Floratorf mix the maximum colonisation levels were reached by $G$. intraradices and Glomus sp (E3). G. intraradices showed a higher level of root colonisation in TKS-1 than in Floratorf, whilst Glomus sp (E3) was favoured by the latter. The other fungi assayed: G. mosse$a e$ and A. laevis maintained a low level of colonisation in both substrates. G. intraradices is consistently the more successful strain in colonising plant roots in both susbtrates. This indicates a higher specificity of this fungus for the host plant. 
Table 2. Effects of AM fungi on GF677 plant growth in TKS-1: perlite mix.

\begin{tabular}{lccccc}
\hline & $\begin{array}{c}\text { Plant } \\
\text { height }\end{array}$ & $\begin{array}{c}\text { Shoot } \\
\text { weight }\end{array}$ & $\begin{array}{c}\text { Stem } \\
\text { diameter }\end{array}$ & $\begin{array}{c}\text { R/S } \\
\text { ratio }\end{array}$ & $\begin{array}{c}\text { \% AM } \\
\text { colonisation }\end{array}$ \\
\hline Control & 26.8 & $4.35 \mathrm{~b}$ & $3.64 \mathrm{~b}$ & $0.83 \mathrm{~b}$ & 0 \\
G. mosseae & 28.8 & $5.14 \mathrm{a}$ & $3.90 \mathrm{ab}$ & $0.52 \mathrm{a}$ & $10 \pm 6$ \\
G. intraradices & 29.7 & $5.46 \mathrm{a}$ & $4.38 \mathrm{a}$ & $0.60 \mathrm{a}$ & $70 \pm 5$ \\
G. sp (E3) & 29.7 & $5.24 \mathrm{a}$ & $3.93 \mathrm{ab}$ & $0.62 \mathrm{a}$ & $8 \pm 2$ \\
A. laevis & 27.4 & $4.79 \mathrm{ab}$ & $3.88 \mathrm{ab}$ & $0.60 \mathrm{a}$ & $18 \pm 9$ \\
\hline
\end{tabular}

Mean of 10 replicates. Values in the same column followed by different letters are significantly different $(\mathrm{p}=0.05)$. Tuckey's test.

Table 3. Effects of AM fungi on GF677 plant growth in Floratorf: perlite mix.

\begin{tabular}{lccccc}
\hline & $\begin{array}{c}\text { Plant } \\
\text { height }\end{array}$ & $\begin{array}{c}\text { Shoot } \\
\text { weight }\end{array}$ & $\begin{array}{c}\text { Stem } \\
\text { diameter }\end{array}$ & $\begin{array}{c}\text { R/S } \\
\text { ratio }\end{array}$ & $\begin{array}{c}\text { \% AM } \\
\text { colonisation }\end{array}$ \\
\hline Control & $12.5 \mathrm{~b}$ & 1.24 & 2.46 & $1.95 \mathrm{~b}$ & 0 \\
G. mosseae & $13.2 \mathrm{ab}$ & 1.35 & 2.43 & $1.58 \mathrm{a}$ & $10 \pm 5$ \\
G. intraradices & $11.7 \mathrm{~b}$ & 1.20 & 2.37 & $1.45 \mathrm{a}$ & $32 \pm 15$ \\
G. sp (E3) & $12.6 \mathrm{~b}$ & 1.21 & 2.33 & $1.59 \mathrm{a}$ & $30 \pm 5$ \\
A. laevis & $15.5 \mathrm{a}$ & 1.48 & 2.23 & $1.45 \mathrm{a}$ & $10 \pm 2$ \\
\hline
\end{tabular}

Mean of 10 replicates. Values in the same column followed by different letters are significantly different $(\mathrm{p}=0.05)$. Tuckey's test.

Glomus sp (E3) root colonisation was substantially different from one substrate to the other. In TKS-1 Glomus sp (E3) colonisation percentage was almost negligible whilst in Floratorf it reached the maximum level of all the fungi assayed, Glomus sp (E3) is clearly favoured by the Floratorf mix stressing the importance of the growing media as the site of specific interactions with the fungus which is a continuous entity with mycelia in the roots and in the substrate (Mosse 1972). The two mixes studied differ very little in their physical properties (Table 1), the original difference in their $\mathrm{pH}$ was compensated with the addition of calcium carbonate to the Floratorf mix.

Many results have correlated low colonisation rates with high nutrient levels of the growing media (Sieverding and Howeler 1985, MiranDA et al. 1989, COOKE et al. 1992), unexpectedly the substrate with the highest nutrient content was best for one of the fungi studied, although for the other fungi studied it decreased or it did not affect the root colonisation. No general statements can be made and each different combina- tion of fungi-substrate and host plant deserves to be studied.

When considering plant growth, the effects of the substrate mixes overcame those of the inoculation treatments. TKS-1 was better than Floratorf in all treatments and for all parameters measured. The inoculation in this substrate mix increased shoot weight ( $G$. mosseae, $G$. intraradices and Glomus sp (E3)) and the stem diameter (G. intraradices). The root/shoot ratio was lower for all the inoculated treatments when compared to the control. In the Floratorf mix although all the inoculated treatments had a significantly lower root/ shoot ratio than the control treatment only the plants colonised by A. laevis showed a significant growth response to the inoculation. The decrease of the R/S ratio is a parameter that is associated to the mycorrhizal symbiosis and our results show that, although no increase of growth was found, the mycorrhiza was functional in all AM treatments. The beneficial effects of the symbiosis might appear in later stages of the plant development, especially in woody host plants 
grown in rich substrates. In the inoculated TKS-1 mixes this functionality was only translated into a significant growth increase for one of the fungi assayed: G. intraradices, which is the one that showed a highest colonisation of the plant roots. SANDERS et al. (1977) found that the most effective fungal strains were those that produced a more rapid and extensive root colonisation, АBBOT and ROBSON (1981) also found a correlation between infectivity of the AMF and effectivity of the symbiosis. However, in the Floratorf mix, there was no correlation between fungal colonisation and plant growth, supporting the findings of SMITH and SMith (1981), Аввот and RobSON (1985) and Graham and Fardelmann (1986). These discrepancies between experiments and the results we have found for the same combination of host plant-fungus but different growing media might be due to initial differences in the symbiosis development rate that can not be seen at the time of harvest. Furthermore the performance of particular fungi in their ability to enhance plant growth lies in the extraradical mycelia development, in the efficiency of this mycelia to absorb and translocate nutrients and how this is translated into an increase of biomass production (SMITH and GIANINAZZI-PEARSON 1988). The performance of a given combination of host plant-AM fungus can be modified by factors such as the growth substrate used (Guttay 1982, Calvet 1989), pH (GRAW 1979) and nutrient levels (CHAMBERs et al. 1980) which might have a direct or indirect effect on the endophyte.

From our work it appears that the growing media is one of the major factors not only in determining the AMF infectivity and symbiosis establishment but also in the regulation of its functionality.

From these results we conclude that even in reach peat based, unsterilised potting mixes the inoculation with a previously selected fungus can enhance plant growth.

Aknowledgements. This work was partially founded by grant no. AGF92-0428 of the Comisión Interministerial de Ciencia y Tecnología (Spanish Ministery of Education and Science).

\section{References}

Aввот, L.K. \& RoBson, A.D. 1981. Infectivity and effectiveness of vesicular-arbuscular mycorrhizal fungi: effect of inoculum type. Australian Journal of Agricultural Research 28: 639-645.

- \& Robson, A.D. 1985. Formation of external Hyphaesoil by four species of vesicular arbuscular mycorrhizal fungi. New Phytologist 99: 245-255.

Aldrufeu, A., Pages, M., Messeguer, J. \& Mele, E. 1983. In vitro rhizogenesis of Rosa $\mathrm{sp}$ in different substrates. Acta Horticulturae 150: 315-323.

BiermanN, B.J. \& Linderman, R.G. 1983. Increased geranium growth using pre-trasplant inoculation with a mycorrhizal fungus. Journal of the American Society of Horticultural Science 108: 972-976.

CAlvet, C. 1989. Micorrizas vesiculo-arbusculares en cultivos intensivos sobre sustratos orgánicos: interacciones con hongos saprófitos y patógenos de la rizosfera. Tesis Doctoral Universidad de Granada.

- Estaun, V. \& CAmprubi, A. 1992. Germination, early mycelial growth and infectivity of a vesicular-arbuscular mycorrhizal fungus in organic susbtrates. Symbiosis 14: 405-411.

Chambers, C. A., Smith, S.E. \& Smith, F.A. 1980. Effects of ammonium and nitrate ions on mycorrhizal infection, nodulation and growth of Trifolium subterraneum. New Phytologist 85: 47-52.
CoOKe, M.A., Widden, P. \& O'Halloran, I. 1992. Morphology, incidence and fertilization effects on the vesicular-arbuscular mycorrhizae of Acer saccharum in a Quebec hardwood forest. Mycologia 84: 422-430.

Estaun, V., Calvet, C. \& Hayman, D.S. 1987. Influence of plant genotypes on mycorrhizal infection: response of three pea cultivars. Plant and Soil 103: 295-298.

Gianinazzi, S., Gianinazzi-Pearson, V. \& Trouvelot, A. 1989. Potentialities and procedures for the use of endomycorrhizas with special emphasis on high value crops. In: Whipps, J.M. \& Lumsden, B. (eds.). Biotechnology of fungi for improving plant growth. Cambridge Univ. Press. Cambridge. U.K. p. 41-54.

Gilmore, A.E. 1971. The influence of endotrophic mycorrhizae on the growth of peach seedlings. Journal of the American Society of Horticultural Science 96: 3537.

Giovanetti, M. \& Mosse, B. 1980. An evaluation of techniques for measuring vesicular-arbuscular mycorrhizal roots. New Phytologist 81: 489-500.

Graham, J.H. \& FardelmanN, D. 1986. Inoculation of citruswith root fragments containing chlamydospores of the mycorrhizal fungus Glomus intraradix. Canadian Journal of Botany 64: 1739-1744.

Graw, D. 1979. The influence of soil pH on the efficiency of vesicular-arbuscular mycorrhizae. New Phytologist 


$$
\text { 82: 687-689. }
$$

GutTAUY, A.J.R. 1982. The growth of three woody plant species and the development of their mycorrhizae in three different plant compost. Journal of the American Society of Horticultural Science 107: 324-331.

Miranda, J.C.C. DE, Harris, P.J. \& Wild, A. 1989. Effects of soil and plant concentrations on vesicular-arbuscular mycorrhizae in sorghum plants. New Phytologist 112: 405-410.

Mosse, B. 1972. The influence of soil type and Endogone strain on the growth of mycorrhizal plants in phosphate deficient soils. Revue d'Ecologie et Biologie du Sol T.IX: 529-537.

NemeC, S. 1987. VA mycorrhizae in horticultural systems. In: Gene \& Safir (eds.). Ecophysiology of VA mycorrhizal plants. CRC press. Boca de Raton. Florida. USA. p. 193-211.

Phillips, J.M. \& HaYMANN, D.S. 1970. Improved procedures for clearing roots and staining parasitic and vewsicular-arbuscular fungi for rapid assessment of infection. Transactions of the British Mycological Society 55: 159-161.

SAnders, F.E., Tinker, P.B., Black, R.L.B. \& Palmery, S.M. 1977. The development of endomycorrhizal root systems. I. Spread of infection and growth promoting effects with four species of vesicular-arbuscular endophyte. New Phytologist 78: 257-268.
Schubert, A., Mazzitelli, M., Ariusso, O. \& Eynard, I. 1990. Effects of vesicular-arbuscular mycorrhizal fungi on micropropagated grapevines: influence of endophyte strain $\mathrm{P}$ fertilization and growth medium. Vitis 29: 5-13.

Sieverding, E. \& Howeler, R.H. 1985. Influence of VA mycorrhizal fungi on cassava yield response to phosphorus fertilization. Plant and Soil 88: 213-221.

SмIтH, F.A. \& Sмітн, S.E. 1981. Mycorrhizal infection and growth of Trifolium subterraneum: comparison of natural and artificial inocula. New Phytologist 88: 311325.

Smith, S.E. \& Gianinazzi-Pearson, V. 1988. Physiological interactions between symbionts in vesicular-arbuscular mycorrhizal plants. Annual Review of Plant Physiology and Plant Molecular Biology 39: 221-244.

VestberG, M. 1992. The effect of growth substrate and fertilizer on the growth and vesicular-arbuscular mycorrhizal infection of three hosts. Agricultural Science in Finland 1: 95-105.

Vidal, M.T., Azcon-Aguilar, C. \& Barea, J.M. 1992. Mycorrhizal inoculation enhances growth and development of micropropagated plants of avocado. HortScience 27: 785-787.

Manuscript received February 1994

\title{
SELOSTUS
}

\section{Arbuskelimykorritsasienten merkitys mikrolisätyn luumun perusrungon kasvuun kahdella turvepohjaisella kasvualustalla}

\author{
Viktoria Estaun, Cinta Calvet ja Amelia Camprubi
}

Departament de Patologia Vegetal, IRTA, Espanja

Kahden turvepohjaisen kasvualustan soveltuvuutta mykorritsasienten siirrostuksiin tutkittiin luumun perusrunkokloonilla GF677 (Prunus persica x Prunus amygdalus). Tutkittavana oli neljä mykorritsasientä: Glomus mosseae,
G. intraradices, G. sp. (E3) ja Acaulospora laevis.

Mykorritsasienten vaikutus perusrungon kasvuun vaihteli eri kasvualustoilla, mikä korostaa kasvualustan merkitystä mykorritsasymbioosissa. 